Article

\title{
The Effect of Light Intensity and Temperature on Flowering and Morphology of Potted Red Firespike
}

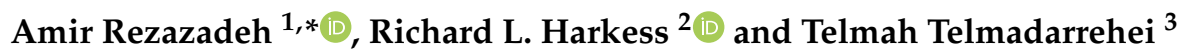 \\ 1 Coastal Research and Extension Center, Mississippi State University, Poplarville, MS 39470, USA \\ 2 Department of Plant and Soil Sciences, Mississippi State University, Starkville, MS 39759, USA; \\ richard.harkess@msstate.edu \\ 3 Department of Sustainable Bioproducts, Mississippi State University, Starkville, MS 39759, USA; \\ tt895@msstate.edu \\ * Correspondence: ar1372@msstate.edu; Tel.: +1-662-312-4626
}

Received: 26 September 2018; Accepted: 20 October 2018; Published: 25 October 2018

\begin{abstract}
Red firespike (Odontonema strictum) is a tropical flowering plant that was selected as a potential flowering potted plant for its attractive red floral spikes. The objective of this study was to evaluate how light intensity, photoperiod, and temperature affect the growth and flowering of firespike. In Experiment 1, plants were grown under 0\%, 45\%, or $65 \%$ shade and two photoperiod conditions; long-day ( $\mathrm{LD}=\geq 14 \mathrm{~h}$ ) and short-day ( $\mathrm{SD}=9 \mathrm{~h}$ ), for 16 weeks. Plants grown under $45 \%$ shade + LD were tallest at $35.9 \mathrm{~cm}$, while plants grown under $65 \%$ shade + SD were shortest at $22.8 \mathrm{~cm}$. During the finishing stage, the number of inflorescences increased when plants were grown under $45 \%$ shade + SD, $45 \%$ shade $+\mathrm{LD}$, and no shade, with 6, 7, and 9 inflorescences, respectively. In addition, the first open flower was observed in the $0 \%$ shade group (control) 92 days after starting the experiment. The time to first open flower increased when the plants were grown under $65 \%$ shade, either under SD or LD. In Experiment 2, plants were grown in controlled environment growth chambers with average daily temperatures of 15,25 , or $35^{\circ} \mathrm{C}$ and an irradiance of $200 \mu \mathrm{mol} \cdot \mathrm{m}^{-2} \cdot \mathrm{s}^{-1}$ for $9 \mathrm{~h}$ per day. Plants grown at $25^{\circ} \mathrm{C}$ were the tallest and had the largest leaf area. Plants grown at 15 and $35{ }^{\circ} \mathrm{C}$ had $28 \%$ and $22 \%$ less leaf area, respectively. The average number of inflorescences in plants grown at $25^{\circ} \mathrm{C}$ was 1.6 , while no inflorescence development was observed in plants grown at 15 or $35^{\circ} \mathrm{C}$ by the termination of the experiment. There were no differences between plant growth index or branch number in response to temperature. Under the experimental conditions tested, the most rapid and uniform flowering of firespike occurred when plants were grown under no shade or at $25^{\circ} \mathrm{C}$.
\end{abstract}

Keywords: Odontonema strictum; short-day; photoperiod; irradiance; shade

\section{Introduction}

Red firespike is a flowering perennial in the Acanthaceae family, native to the tropical and sub-tropical regions of Central America [1]. The plant has potential for commercial introduction as a flowering potted plant because of its attractive red spikes of flowers and shiny green leaves. Daylength is a controlling factor for flower induction and initiation for many plants. Plants flowering in response to photoperiod have been classified as long-day (LD), day neutral (DN) and short-day (SD) plants [2]. Long day plants flower when the daylength exceeds their critical photoperiod. Day neutral plants are insensitive to daylength, and SD plants flower when the daylengths are less than a critical photoperiod. Short day and LD plants may also be categorized as facultative or obligate for their photoperiod requirement, where flowering is hastened by photoperiod in facultative plants or a critical photoperiod is required in obligate plants [2]. Red firespike is reported to be a SD plant [3]. 
In addition to photoperiod, light intensity can influence the flowering of many ornamental plants [4-6]. In a study of geranium (Pelargonium spp.), high intensity discharge (HID) supplemental lighting reduced production time [7]. Time to anthesis of cut rose (Rosa spp.) was decreased 3-10 days when using HID lamps [8]. Armitage [9] studied the effect of light intensity on various field-grown cut-flower species using full sun, $55 \%$ or $67 \%$ shade treatments. Shade treatments led to a longer stem and lower flower yield in most species tested. Low irradiance also increased internode elongation in various cut flower species [10]. While plants grown in shade have longer flower stems than those in full sun, high irradiance usually results in greater flower production [11]. Flowering may be reduced or delayed as irradiance is reduced [12,13]. In a study by Zhang et al. [6], 'Summer Pastels' yarrow (Achillea millefolium) flowered after 57, 45, and 37 days when receiving 100, 200, or $300 \mu \mathrm{mol} \cdot \mathrm{m}^{-2} \cdot \mathrm{s}^{-1}$ irradiance, respectively. Erwin and Warner [5] also reported early flowering in 11 herbaceous ornamental species when plants were grown under ambient daylight plus $25-50 \mu \mathrm{mol} \cdot \mathrm{m}^{-2} \cdot \mathrm{s}^{-1}$ light intensity from high-pressure sodium (HPS) lamps for up to $18 \mathrm{~h}$ daily compared to plants grown under ambient daylight alone. Armitage and Tsujita [14] found supplemental HPS lighting hastened flowering in some cultivars of geranium compared with plants grown under natural daylight conditions. Supplemental lighting increases the total light received by the plant in a day and is known as the daily light integral (DLI). Increasing DLI can promote growth rate by increasing photosynthesis [15].

In addition to photoperiod and light intensity, air temperature influences plant development. Adams et al. [16] investigated the effect of temperature on the time of floral initiation in chrysanthemum (Chrysanthemum $x$ grandiflorum). Flowering occurred most rapidly in plants grown at a mean temperature of $20.4{ }^{\circ} \mathrm{C}$, while the time of floral initiation was significantly delayed at $9.6^{\circ} \mathrm{C}$. Karlsson et al. [17] also studied the effect of temperature on flower development in chrysanthemum and found the optimum temperature for floral induction to visible bud was $21.3^{\circ} \mathrm{C}$.

There are strong interactions between temperature and photoperiod that influence flowering in many species. In most photoperiodic plants, flowering occurs in response to a critical photoperiod, but it has been reported that optimum temperature and favorable photoperiod can accelerate flowering within critical limits [18]. For example, 'Koral' lipstick vine (Aeschynanthus spp.) flowers as a day-neutral plant under $18{ }^{\circ} \mathrm{C}$, but as a long-day plant at $24{ }^{\circ} \mathrm{C}$ [19]. Thanksgiving cactus (Schlumbergera truncata) does not respond to photoperiod when grown above $21^{\circ} \mathrm{C}$, and is a SD plant at temperatures between 17 and $18{ }^{\circ} \mathrm{C}$, but is day neutral for flowering when grown between 10 and $15{ }^{\circ} \mathrm{C}$ [20]. In addition, plants respond to temperature and photoperiod signals differently at various developmental stages [21].

To our knowledge, no studies have been published on the effect of photoperiod, light intensity, or temperature during the vegetative or reproductive stage of growth, development, and flowering of firespike. The aims of the following study were to: (1) investigate the effects of light intensity and photoperiod on growth and flowering of firespike, and (2) quantify the effects of temperature on flowering time and plant quality of firespike.

\section{Materials and Methods}

\subsection{Plant Material and Culture}

Stock plants of red firespike were maintained in a vegetative stage by extending the daylength by supplemental lighting from 2200 to $0200 \mathrm{HR}$ using overhead $60-\mathrm{W}$ (PPF of $\approx 3$ to $4 \mu \mathrm{mol} \cdot \mathrm{m}^{-2} \cdot \mathrm{s}^{-1}$ at canopy level) incandescent lamps to limit the possibility of floral initiation occurring before experimental treatments were started. In September 2014, eighty single node cuttings of red firespike were rooted in 32-cell (165 mL individual cell volume) plug trays (Root tutor; Summit Plastic, Akron, $\mathrm{OH}$, USA) filled with a commercial soilless medium composed of $\approx 70$ to $80 \%$ Canadian sphagnum peatmoss and $\approx 30 \%$ perlite (Sunshine Mix 1 ; Sun Gro Horticulture, Bellevue, WA, USA) under a mist bench. Four weeks later, the rooted cuttings were transplanted into $15 \mathrm{~cm}$ diameter (1.7 L volume) 
round containers containing the same substrate. Plants were grown under an artificial long day until the shade treatment was started. Air temperature was maintained at $24 \pm 1{ }^{\circ} \mathrm{C}$. Plants were irrigated as necessary and a liquid fertilizer was provided weekly with the irrigation (Peters Peat-Lite 20-10-20; Scotts, Marysville, OH, USA). Plant material was maintained in a glass-glazed greenhouse with exhaust fan and evaporative-pad cooling, radiant hot water, and retractable shade curtains controlled by an environmental computer at Mississippi State University, Mississippi State, MS (lat. $33^{\circ} \mathrm{N}$ ).

\subsection{Experiment 1}

For Experiment 1, in October 2014, plants were moved to benches $\approx 1.2 \mathrm{~m}$ wide and $3 \mathrm{~m}$ long in a glass-glazed greenhouse with a constant temperature of $24 \pm 1{ }^{\circ} \mathrm{C}$. Plants were exposed to different light intensities as a percent shade from ambient light levels. Shade treatments were constructed by stretching one or two layer of black woven shade cloth (DeWitt, Sikeston, MO, USA) $\approx 0.5 \mathrm{~m}$ above the plants. One layer of shade cloth was used to provide $\approx 45 \%$ shade, two layers created $\approx 65 \%$ shade, and $0 \%$ shade (no shade cloth) was a control. A quantum photometer (LI- 188B; LI-COR, Lincoln, NE, USA) was used to evaluate light levels. In addition, to study the interaction of light intensity and daylength, plants under different shade levels were placed under natural short day $(\approx 11 \mathrm{~h}$ daylength) or natural daylength with day-extension lighting from overhead $60-\mathrm{W}$ incandescent lamps (PPF of $\approx 3$ to $4 \mu \mathrm{mol} \cdot \mathrm{m}^{-2} \cdot \mathrm{s}^{-1}$ at canopy level) from 2200 to $0200 \mathrm{HR}$ to provide a LD photoperiod. The $0 \%$ shade control group was only grown under natural short days. Air and substrate temperatures were recorded every $30 \mathrm{~s}$, and the averages were logged every $15 \mathrm{~min}$ by a data logger (WatchDog Model 1525; Spectrum Technologies, Inc., Aurora, IL, USA). Five amplified quantum sensors (lightscout, Aurora, Illinois 60504) measured PPF every $30 \mathrm{~s}$ under each lighting treatment, and the average of each sensor was logged every $15 \mathrm{~min}$ by a data logger.

Data were collected for 16 weeks after cuttings were taken from stock plants. Plant height (from the soil level to the apical tip of the plant) was measured at the termination of the study. Total plant dry weight, leaf number below the inflorescence, days to first open flower, and number of plants reaching first floret opening (anthesis) were counted. Pots were arranged in a randomized complete design within each experiment. Statistical analyses were conducted using the general linear models procedure of SAS (version 9.3; SAS Institute, Cary, NC, USA). Means were separated using the least significant difference test at $P \leq 0.05$.

\subsection{Experiment 2}

On 21 November 2014, three constant temperature treatments of 15,25 , and $35^{\circ} \mathrm{C}$ and a relative humidity (RH) of $70 \pm 5 \%$ were established using three growth chambers. A 9-h short-day photoperiod was provided for all plants using a combination of cool-white fluorescent and incandescent lamps from 0800 to $1700 \mathrm{HR}$ at $200 \mu \mathrm{mol} \cdot \mathrm{m}^{-2} \cdot \mathrm{s}^{-1}$. Thirty plants of red firespike transplanted into $15 \mathrm{~cm}$ diameter pots were provided with the same propagation procedure, soilless media, and greenhouse environment as previously described for Experiment 1. Plants were maintained in growth chambers until the termination of the experiment. Plants were irrigated as necessary and a liquid fertilizer was provided weekly with irrigation as described for Experiment 1 . Air temperature was recorded for each growth chamber every $30 \mathrm{~s}$ by a data logger (WatchDog Model 1525; Spectrum Technologies, Inc., Aurora, IL, USA). Each quantum sensor (lightscout, Aurora, Illinois 60504) installed in the growth chambers measured PPF every $30 \mathrm{~s}$ under each lighting treatment, and the average of each sensor was logged every 15 min by a data logger.

For Experiment 2, data were collected 16 weeks after cuttings were taken from stock plants. Final plant height, number of branches over $4 \mathrm{~cm}$ in length, total plant dry weight, total leaf area (LI-3100 area meter; LI-COR, Lincoln, NE, USA), number of leaves below the inflorescence, and average number of inflorescences per plant were recorded. A plant growth index (GI) was calculated as $\mathrm{GI}=\pi \times(\text { average width } / 2)^{2} \times$ height. A randomized complete design with treatments replicated 10 times was used for Experiment 2. Data were analyzed using the GLM procedure of SAS (version 9.3; 
SAS Institute, Cary, NC, USA) to evaluate the effect of temperature on growth and flowering of firespike. Means were separated using the least significant difference test at $P \leq 0.05$.

\section{Results}

Shade treatments affected growth and flowering of red firespike (Table 1). Significant differences in plant height due to shading occurred until harvest. Plants were tallest when grown under no shade (control) or $45 \%$ or $65 \%+\mathrm{LD}$. Shade treatments alone or combined with short days resulted in the shortest plants. Plant dry weight decreased as shade level increased from $45 \%$ to $65 \%$ in both the LD and SD photoperiod (Table 1). Plant dry weight was highest in $45 \%$ shade + LD and lowest in $65 \%$ $+\mathrm{SD}$ (Table 1). Leaf number below the inflorescence was greatest under LD regardless of the shade level. In general, higher light intensity or longer duration increased vegetative growth. Plants grown under the control condition had the greatest number of plants flowering, and $45 \%$ shade resulted in more flowering plants than $65 \%$ shade, regardless of photoperiod. Light intensity also affected the time to a visible flower, where the time to first open floret was hastened as shade level decreased in both LD and SD. However, the control plants reached the first open floret only 92 days after starting the experiment (Table 1).

Table 1. Effects of light intensity treatments on plant height, number of leaves below inflorescence, plant dry weight, number of plants flowering, and days to first open flower in red firespike (Odontonema strictum). Plants were grown under $0 \%, 45 \%$, or $65 \%$ shade under two photoperiod conditions; long-day (LD) or short-day (SD).

\begin{tabular}{|c|c|c|c|c|c|c|}
\hline Photoperiod & $\begin{array}{c}\text { Shade Level } \\
(\%)\end{array}$ & $\begin{array}{l}\text { Plant Height } \\
(\mathrm{cm})\end{array}$ & $\begin{array}{c}\text { Leaves below } \\
\text { Inflorescence (No.) }\end{array}$ & $\begin{array}{l}\text { Plant dry } \\
\text { Weight (g) }\end{array}$ & $\begin{array}{c}\text { Plants } \\
\text { Flowering (No.) }\end{array}$ & $\begin{array}{l}\text { Days to First } \\
\text { Open Flower }\end{array}$ \\
\hline Control (SD) & 0 & $32.8 \mathrm{a}^{\mathrm{z}}$ & $8.6 \mathrm{~b}$ & $19.3 \mathrm{ab}$ & $9 a$ & $92.1 \mathrm{e}$ \\
\hline \multirow[t]{2}{*}{ SD } & 45 & $23.6 \mathrm{~b}$ & $8.0 \mathrm{c}$ & $18.1 \mathrm{bc}$ & $6 a b$ & $99.6 \mathrm{~d}$ \\
\hline & 65 & $22.8 \mathrm{~b}$ & $8.0 \mathrm{c}$ & $15.9 \mathrm{~d}$ & $1 \mathrm{c}$ & $138.7 \mathrm{a}$ \\
\hline \multirow[t]{2}{*}{ LD } & 45 & $35.9 \mathrm{a}$ & $10.0 \mathrm{a}$ & $20.0 \mathrm{a}$ & $7 \mathrm{ab}$ & $110.4 \mathrm{c}$ \\
\hline & 65 & $32.8 \mathrm{a}$ & $10.0 \mathrm{a}$ & $17.4 \mathrm{c}$ & $4 \mathrm{bc}$ & $133.1 \mathrm{~b}$ \\
\hline
\end{tabular}

${ }^{\mathrm{z}}$ Means within a column followed by the same letter are not significantly different according to the least significant difference means comparison test at $P=0.05$.

Plant growth index was greater at $25^{\circ} \mathrm{C}$ than $15^{\circ} \mathrm{C}$, and temperature affected final plant height (Table 2). The maximum plant height was obtained when plants were grown at $25^{\circ} \mathrm{C}$, significantly decreasing at $35^{\circ} \mathrm{C}$, with the shortest plants at $15^{\circ} \mathrm{C}$. Dry weight followed a similar pattern where plants grown at $25^{\circ} \mathrm{C}$ had the greatest dry weight, and it decreased in plants grown at 15 or $35^{\circ} \mathrm{C}$. Plants grown at $35{ }^{\circ} \mathrm{C}$ and $15{ }^{\circ} \mathrm{C}$ had lower leaf areas; $22 \%$ and $28 \%$, respectively, compared with plants grown at $25^{\circ} \mathrm{C}$ (Table 2). At the termination of the experiment ( 20 weeks after taking cuttings), no flowering was observed in plants grown at 15 or $35^{\circ} \mathrm{C}$. However, plants grown at $25^{\circ} \mathrm{C}$ averaged 1.6 inflorescences per plant. Leaf number below the first inflorescence was 10.4 in plants grown at $25{ }^{\circ} \mathrm{C}$. Since plants grown at 15 or $35^{\circ} \mathrm{C}$ did not flower, there were no inflorescences and consequently, the leaves below inflorescence was not counted.

Table 2. The effects of temperature on plant height, plant growth index, number of branches, plant dry weight, leaf area, number of leaves below inflorescence and number of inflorescences per plant in red firespike (Odontonema strictum).

\begin{tabular}{cccccccc}
\hline $\begin{array}{c}\text { Temperature } \\
\left({ }^{\circ} \mathbf{C}\right)\end{array}$ & $\begin{array}{c}\text { Plant } \\
\text { Height } \mathbf{( c m})\end{array}$ & $\begin{array}{c}\text { Growth } \\
\text { Index }\left(\mathbf{c m}^{\mathbf{3}}\right)\end{array}$ & $\begin{array}{c}\text { Branches } \\
\mathbf{( N o})\end{array}$ & $\begin{array}{c}\text { Plant Dry } \\
\text { Weight } \mathbf{( g )}\end{array}$ & $\begin{array}{c}\text { Leaf Area } \\
\left(\mathbf{c m}^{\mathbf{2}}\right)\end{array}$ & $\begin{array}{c}\text { Leaves Below } \\
\text { Inflorescence }(\mathbf{N o})\end{array}$ & $\begin{array}{c}\text { Inflorescences } \\
(\mathbf{N o})\end{array}$ \\
\hline 15 & $18.4 \mathrm{c}^{\mathrm{z}}$ & $19183 \mathrm{~b}$ & $2.4 \mathrm{a}$ & $21.0 \mathrm{~b}$ & $1973.4 \mathrm{~b}$ & - & $0 \mathrm{~b}$ \\
25 & $49.2 \mathrm{a}$ & $24074 \mathrm{a}$ & $3.0 \mathrm{a}$ & $36.8 \mathrm{a}$ & $2757.4 \mathrm{a}$ & 10.4 & $1.6 \mathrm{a}$ \\
35 & $31.8 \mathrm{~b}$ & $21,068 \mathrm{ab}$ & $2.2 \mathrm{a}$ & $26.0 \mathrm{~b}$ & $2142.4 \mathrm{~b}$ & - & $0 \mathrm{~b}$ \\
\hline
\end{tabular}

${ }^{\mathrm{z}}$ Means within a column followed by the same letter are not significantly different according to the least significant difference means comparison test at $P=0.05$. 


\section{Discussion}

Light intensity greatly affected growth and flowering of red firespike. Higher light intensity in the control and $45 \%$ shade + LD treatments resulted in increased plant height. Increasing plant height under increased light intensity and LD may be due to increased irradiance received by the plants during a $24 \mathrm{~h}$ cycle and, consequently, increased growth rate resulting from more photosynthesis. Increased plant height under a higher light intensity in Cardinal flower (Sinningia cardinalis (Lehm.) H. E. Moor) has also been reported previously by Hee Kim et al. [22]. This result is not in agreement with earlier research in which $67 \%$ shade increased plant height in various field-grown cut-flower species [9] indicating that firespike may not use a shade avoidance mechanism to overcome a lower light intensity problem. Plant dry weight also increased when the conditions changed from a low to high light intensity.

A greater shade level (65\%) delayed flowering by 41 and 46 days in LD and SD, respectively, compared to the control, a result that was in agreement with previous studies reporting delayed flowering under low light intensity $[6,8,9,12,23]$. Plants grown in SD initiated flowering earlier than those in LD. Red firespike initiated flowering in both LD and SD, indicating that red firespike may be a facultative SD plant. Plants grown under control, $45 \%$ and $65 \%$ shade with SD conditions produced fewer leaves below the inflorescence (Table 1). Cremer et al. [23] reported that a higher light intensity resulted in a lower leaf number below the inflorescence. The firespike flowering response to SD would also limit the number of additional leaves produced before flowering compared to plants under LD. A significant decrease in inflorescence number was observed as the shade level increased, indicating that in addition to daylength, the amount of light is also an important factor in flower initiation and development. Firespike required greater light intensity to maximize inflorescence number. The increased number of inflorescences with increasing light intensity is likely associated with increased irradiance for photosynthesis. A similar result was reported by Kamoutsis et al. [24] in which gardenia (Gardenia spp.) produced 30\% fewer flowers when exposed to $67 \%$ shade.

Plants grown at $25^{\circ} \mathrm{C}$ flowered after 92 days, while plants grown at 15 and $35^{\circ} \mathrm{C}$ failed to flower before termination of the experiment. A delay or inhibition of flowering under high temperatures has been reported in other plants [16-18,25]. The physiological mechanism of inhibition of flowering at high temperatures is not understood. It has been suggested that a high temperature may interrupt synthesis or interconversion of plant hormones such as cytokinin or gibberellin [26,27], or that high temperatures weaken the floral signal effects.

Plants reached maximum height at $25^{\circ} \mathrm{C}$, while higher temperatures led to shorter plants. This agrees with findings of Nordli et al. [28], where temperatures of $24{ }^{\circ} \mathrm{C}$ enhanced total shoot length and resulted in longer internodes in hydrangea (Hydrangea macrophylla). They also found that high temperatures delayed flowering, increased the number of leaves below the inflorescence and reduced the quality of the final product. The dry weight of firespike increased with increasing the temperature from 15 to $25{ }^{\circ} \mathrm{C}$, however, increasing the temperature further to $35^{\circ} \mathrm{C}$ decreased plant dry weight. Similar results were observed in 'Angel Mist' summer snapdragon (Angelonia angustifolia) where shoot dry weight increased as the temperature increased from 15 to $30^{\circ} \mathrm{C}$ [29]. Increasing the temperature from 15 to $25^{\circ} \mathrm{C}$ enhanced leaf expansion, however, $35^{\circ} \mathrm{C}$ resulted in less leaf expansion. Similar results were observed in orchids, where increasing the temperature from 14 to $25^{\circ} \mathrm{C}$ increased leaf expansion, but leaf development was retarded at temperatures above $25^{\circ} \mathrm{C}$ [30]. In conclusion, $25^{\circ} \mathrm{C}$ at $200 \mu \mathrm{mol} \cdot \mathrm{m}^{-2} \cdot \mathrm{s}^{-1}$ light intensity resulted in rapid growth and development of red firespike. Moderate temperatures along with high irradiance (no shade) and SD are recommended for promoting faster flowering.

Author Contributions: This work was a product of the combined effort of all of the authors. All authors conceptualized and designed the study. A.R. performed the experiments, collected and analyzed the data, and wrote the manuscript with assistance from all other authors, mainly T.T. R.L.H. provided technical advice and assistance during the study, and revised and improved the manuscript.

Funding: This research received no external funding.

Conflicts of Interest: The authors declare no conflicts of interest. 


\section{References}

1. Daniel, T.F. Revision of Odontonema (Acanthaceae) in Mexico. Contrib. Univ. Mich. Herb. 1995, 20, $147-171$.

2. Thomas, B.; Vince-Prue, D. Photoperiodism in Plants, 2nd ed.; Academic Press: New York, NY, USA, 1997; pp. 1-26.

3. Garofalo, J.F. Short-Day Shrubs for Fall and Winter Color; Univ. Florida Coop. Ext. Ser. Fact Sheet No. 38. 4; University of Florida: Gainesville, FL, USA, USA; 2002.

4. Dole, J.M.; Wilkins, H.F. Floriculture: Principles and Species; Prentice-Hall: Upper Saddle River, NJ, USA, 1999.

5. Erwin, J.E.; Warner, R. Determination of photoperiodic response group and effect of supplemental irradiance on flowering of several bedding plant species. Acta Hortic. 2002, 580, 95-100. [CrossRef]

6. Zhang, D.; Armitage, A.M.; Affolter, J.M.; Dirr, M.A. Environmental control of flowering and growth of Achillea millefolium L. 'Summer Pastels'. HortScience 1996, 31, 364-365.

7. Quatchak, D.J.; White, J.W.; Holcomb, E.J. Temperature, supplemental lighting, and chlormequat chloride effects on flowering of geranium seedlings. J. Am. Soc. Hortic. Sci. 1986, 111, 376-379.

8. Tsujita, M.J. High intensity supplementary radiation of roses. In Roses; Langhans, R.W., Ed.; Roses Inc.: Haslett, MI, USA, 1987; pp. 171-186.

9. Armitage, A.M. Shade affects yield and stem length of field-grown cut flower species. HortScience 1991, 26, 1174-1176.

10. Armitage, A.M.; Seager, N.G.; Warrington, I.J.; Greer, D.H. Response of Oxypetalum caeruleum to irradiance, temperature and photoperiod. J. Am. Soc. Hortic. Sci. 1990, 115, 910-914.

11. Halevy, A.H. Light and autonomous induction. In Light and the Flowering Process; Vince-Prue, D., Thomas, B., Cockshull, K.E., Eds.; Academic Press: New York, NY, USA, 1984; pp. 65-73.

12. Armitage, A.M.; Wetzstein, H.Y. Influence of light intensity on flower initiation and differentiation in hybrid geranium. HortScience 1984, 19, 114-116.

13. Craig, R.; Walker, D.E. The flowering of Pelargonium hortorum Bailey seedlings as affected by cumulative solar energy. Proc. Am. Soc. Hortic. Sci. 1963, 83, 772-776.

14. Armitage, A.M.; Tsujita, M.J. The effect of supplemental light source, illumination and quantum flux density on the flowering of seed-propagated geraniums. J. Hortic. Sci. 1979, 54, 195-198. [CrossRef]

15. Nemali, K.S.; van Iersel, M.W. Light effects on wax begonia: Photosynthesis, growth respiration, maintenance respiration, and carbon use efficiency. J. Am. Soc. Hortic. Sci. 2004, 129, 416-424.

16. Adams, S.R.; Pearson, S.; Hadley, P. The effect of temperature on inflorescence initiation and subsequent development in chrysanthemum cv. Snowdon (Chrysanthemum morifolium Ramat.). Sci. Hortic. 1998, 77, 59-72. [CrossRef]

17. Karlsson, M.G.; Heins, R.D.; Erwin, J.E.; Berghage, R.D.; Carlson, W.H.; Biernbaum, J.A. Irradiance and temperature effects on time of development and flower size in chrysanthemum. Sci. Hortic. 1989, 39, 257-267. [CrossRef]

18. Adams, S.R.; Pearson, S.; Hadley, P.; Patefield, W.M. The effects of temperature and light integral on the phases of photoperiod sensitivity in Petunia hybrida. Ann. Bot. 1999, 83, 263-269. [CrossRef]

19. Whitton, B.; Healy, W. Flowering of Aeschynanthus 'Koral'. HortScience 1991, 26, 858-859.

20. Roberts, R.H.; Struckmeyer, B.E. Further studies on the effects of temperature and other environmental factors upon the photoperiodic responses of plants. J. Agric. Res. 1939, 59, 699-709.

21. Wang, Z.; Acock, M.C.; Acock, B. Phases of development to flowering in opium poppy (Papaver somniferum L.) under various inductive photoperiods. HortScience 1998, 32, 999-1002.

22. Kim, J.H.; Lee, A.K.; Roh, M.S.; Suh, J.K. The effect of irradiance and temperature on the growth and flowering of Sinningia cardinalis. Sci. Hortic. 2015, 2015. 194, 147-153. [CrossRef]

23. Cremer, F.; Havelange, A.; Saedler, H.; Huijser, P. Environmental control of flowering time in Antirrhinum majus. Physiol. Plant. 1998, 104, 345-350. [CrossRef]

24. Kamoutsis, A.P.; Chronopoulou-Sereli, A.G.; Paspatis, E.A. Paclobutrazol affects growth and flower bud production in gardenia under different light regimes. HortScience 1999, 34, 674-675.

25. Sakanishi, Y.; Imanishi, H.; Ishida, G. Effect of temperature on growth and flowering of Phalaenopsis amabilis. Bull. Univ. Osaka 1980, 32, 1-9.

26. Chou, C.C.; Chen, W.S.; Huang, K.L.; Yu, H.C.; Liao, L.J. Changes in cytokinin levels of Phalaenopsis leaves at high temperatures. Plant Physiol. Biochem. 2000, 38, 309-314. [CrossRef] 
27. Su, W.R.; Chen, W.S.; Koshioka, M.; Mander, L.N.; Hung, L.S.; Chen, W.H.; Fu, Y.M.; Huang, K.L. Changes in gibberellin levels in the flowering shoot of Phalaenopsis hybrida under high temperature conditions when flower development is blocked. Plant Physiol. Biochem. 2001, 39, 45-50. [CrossRef]

28. Nordli, E.F.; Strøm, M.; Torre, S. Temperature and photoperiod control of morphology and flowering time in two greenhouse grown Hydrangea macrophylla cultivars. Sci. Hortic. 2011, 127, 372-377. [CrossRef]

29. Miller, A.; Armitage, A.M. Temperature, irradiance, photoperiod, and growth retardants influence greenhouse production of Angelonia angustifolia Benth. Angel Mist Series. HortScience 2002, 37, 319-321.

30. Lopez, R.G.; Runkle, E.S. The effect of temperature on leaf and flower development and flower longevity of Zygopetalum redvale 'Fire Kiss' orchid. HortScience 2004, 39, 1630-1634.

2018 by the authors. Licensee MDPI, Basel, Switzerland. This article is an open access article distributed under the terms and conditions of the Creative Commons Attribution (CC BY) license (http://creativecommons.org/licenses/by/4.0/). 